Original Research

\title{
Controlling Nitrate and Heavy Metals Content in Leeks (Allium porrum L.) Using Arbuscular Mycorrhizal Fungi Inoculation
}

\author{
Lucie Kučová 1 , Tomáš Kopta $^{1 *}$, Agnieszka Sękara², Robert Pokluda ${ }^{1}$ \\ ${ }^{1}$ Department of Vegetable Growing and Floriculture, Faculty of Horticulture, Mendel University in Brno, \\ Valtická 337, 69144 Lednice, Czech Republic \\ ${ }^{2}$ Department of Vegetable and Medicinal Plants, Faculty of Biotechnology and Horticulture, \\ University of Agriculture in Krakow, 29 Listopada 54, Kraków, Poland
}

Received: 7 March 2017

Accepted: 15 May 2017

\begin{abstract}
This article concerns the influence of arbuscular mycorrhizal symbioses on the accumulation of nitrates and heavy metals in leeks (Allium porrum L.) of the variety Terminal. Leek plants were cultivated under field conditions in 2014 and 2015. A comparison was made of the effects of inoculation with three species of arbuscular mycorrhizal fungus: Rhizophagus intraradices (RI), Claroideoglomus claroideum (CC), and Funneliformis mosseae (FM), plus combinations of these against untreated control. Colonisation in the control was $9.5 \%$ in 2014 and $10.7 \%$ in 2015 . The highest level of colonisation in the treated variants reached $60.0 \%$ (RI+FM in 2014) and 58.9\% (RI+CC in 2015). The influence on nitrates content in leek white shaft tissues was monitored in the variant $\mathrm{CC}$ and variants combining two mycorrhizal fungus. The lowest nitrates content was shown in the variants RI+FM in $2014\left(44.6 \mathrm{mg} \cdot \mathrm{kg}^{-1}\right)$ and $\mathrm{RI}+\mathrm{CC}$ in 2015 $\left(12.2 \mathrm{mg} \cdot \mathrm{kg}^{-1}\right)$. From the results, we can state that since the climatic conditions highly affected mycorrhizal symbosis development, accumulation of nitrates and heavy metals was significantly differentiated between experimental years.
\end{abstract}

Keywords: AMF inoculation, heavy metals, Claroideoglomus, food safety, Funneliformis, Rhizophagus, leek

\section{Introduction}

Arbuscular mycorrhizal fungi occur in the soil of almost all ecosystems and are commonly associated with a majority

*e-mail: tomas.kopta@mendelu.cz of terrestrial plants by forming the mutual symbiosis [1]. Mycorrhizal mycelium acts as an intermediary between the soil and the plant, absorbing nutrients and water from soil and delivering them to the host root [2]. Among the most widespread types of mycorrhizal symbiosis (about $95 \%$ of vascular plants) are the arbuscular mycorrhizae (AM) [3]. The main representatives of this group are the genera Acaulospora, Endogone, Gigaspora, Glomus, and 
others [4]. Arbuscular mycorrhizal fungi draw the energy needed for their sustenance from the host plant. In return they give the plant certain minerals, primarily phosphorus, mineral nitrogen, and in some cases also nitrogen released from organic substances that would otherwise be less accessible for the plant [5]. Smith [6] sees as the main benefit of arbuscular mycorrhizae the ability to obtain phosphates from a greater distance than can be reached by uninfected roots or root hairs. AMF have been shown not only to improve plant nutrition, but they also interfere with the phytohormone balance of the plant, thereby influencing plant development and mitigating the effects of environmental stresses [7]. AMF are known to present an effective and sustainable tool to enhance drought tolerance in horticultural crops [8].

The influence of the treatment of plants with arbuscular mycorrhizal fungi on the nutritional parameters of the plant has been confirmed by many studies. It always depends on the species of host plant and the specific fungus that forms the mycorrhizal symbiosis. The inoculation of a plant with mycorrhizal fungi frequently increases the content of phosphorus, zinc, nitrogen, and potassium in plant tissues [6, 8-10]. Other experiments demonstrated, for example, increased content of copper and iron in lettuce [11], selenium in garlic [12] phenolic substances, flavonoids and lignin compounds in cucumber [13], carotenoids in pepper [14], sugar in tomato [15-16], lycopene in tomato [17-18], or organic compounds containing sulphur in Welsh onion plants [19]. Some research was focused on leek because of the economic importance of this crop and long vegetation period, allowing mycorrhizal fungi to develop the symbiotic relationship. The studies of Malik et al. [20] provide information that the selection of mycorrhizal communities from the roots of different plant cultivars is a valuable method to enhance the growth and quality of leeks (increase yield and polyphenol content). Sorensen et al. [12] demonstrated that pre-inoculation of leek increased the shoot and root concentrations of $\mathrm{P}, \mathrm{Zn}$, $\mathrm{Cu}$, and $\mathrm{N}$, and plant production. Inoculation with $\mathrm{AM}$ fungi had the potential to enhance crop nutrient uptake, including trace elements.

An important role in inoculation with arbuscular mycorrhizal fungi is also played by the question of the accumulation of harmful substances, such as heavy metals or nitrates. Paun et al. [21] investigated how AM fungi protect plants from toxic elements (HMs) by retaining them in their root systems, and they also have the potential to change and modify the rhizosphere environment [21]. Nitrates are not in themselves harmful until they are reduced into nitrites by bacteria living in the human digestive tract. Nitrates might react with dietary amines to form carcinogenic nitrosamines. Nitrates are dangerous to infants younger than six months [11]. The aim of this work was to verify the influence of selected species of AM fungi on the content of nitrates and selected heavy metals in leek plants (Allium porrum L.). We formulated the experimental hypotheses that 1) AMF inoculation can decrease nitrates level in leek and 2) an additional challenge is to include mixed communities of different
AMF species to investigate their theoretical functional complementarity.

\section{Methods and Materials}

\section{Experimental Design}

The experiment took place in 2014-15 on land of the Faculty of Horticulture in Lednice, Mendel University in Brno, Czech Republic. The leek (Allium porrum L.), variety Terminal (MORAVOSEED, Czech Republic), was selected as the material of the experiment. This is a semi-early variety, intended for summer and autumn harvesting. The leek was sown together with a precise amount of inoculum of arbuscular mycorrhizal fungus (AM) in cultivation trays with 160 cells. The substrate used was Klasmann TS 3 STANDARD, and the $\mathrm{pH}$ was 5.5-6.5. The electrical conductivity of the substrate is $30 \mathrm{mS} \mathrm{m}{ }^{-1}$. The nutrient content of the substrate is as follows: $100 \mathrm{mg} \mathrm{l}^{-1} \mathrm{~N}, 70-150 \mathrm{mg} \mathrm{l}^{-1} \mathrm{P}_{2} \mathrm{O}_{5}, 140-300 \mathrm{mg} \mathrm{l}^{-1}$ $\mathrm{K}_{2} \mathrm{O}$, and 60-100 $\mathrm{mg} \mathrm{l}^{-1} \mathrm{Mg}$ (Pasic.cz 2015).

Three variants of single-genus AM inoculum were tested: RI (Rhizophagus intraradices BEG 140), CC (Claroideoglomus claroideum BEG 210), FM (Funneliformis mosseae BEG 95), and three mixed variants labelled: $\mathrm{RI}+\mathrm{CC}, \mathrm{CC}+\mathrm{FM}$, and $\mathrm{RI}+\mathrm{FM}$. An untreated control variant $(\mathrm{C})$ was also used. The dosing of individual AM inoculum was $0.015 \mathrm{~g}$ to $1 \mathrm{~cm}^{3}$ of substrate as recommended by the producer [22]. The approximate content of live spores in fungal inoculum was established prior to the initiation of the experiment. In 2014-15 the visual number of spores in $1 \mathrm{~g}$ inoculum soaked in distilled water was as follows: Claroideoglomus claroideum BEG 210 (23/25), Funneliformis mosseae BEG 95 (15/17), and Rhizophagus intraradices BEG 140 (28/23). Each cultivation tray was isolated to avoid contamination of variants when watering. After an ensuing minimum twomonth pre-cultivation period in a greenhouse, the plants were planted in the experimental plot with randomly generated blocks for individual variants (seven rows, five repetitions, 20 plants in the repetitions). Sowing in individual years took place on $8 / 4 / 2014$ and $25 / 3 / 2015$, and planting on the experimental plot on 11/6/2014 and $2 / 6 / 2015$. The dates of harvesting were 21/10/2014 and 26/10/2015. The plant spacing was $0.1 \times 0.5 \mathrm{~m}$ and the plot was irrigated by microspraying. Soil analysis showed $\mathrm{pH}\left(\mathrm{H}_{2} \mathrm{O}\right) 6.4$ in 2014 and 6.8 in 2015 and organic carbon content of $1 \%$ for both years; the nutrients content was within the range recommended for leeks. Total HMs content was comparable with background levels detected in uncontaminated soils [23]. During the vegetation in the field, the standard cultivation procedures recommended for leeks was performed.

\section{Laboratory Analyses}

After harvest, we assessed the colonisation of roots by AM fungi out visually using staining with trypan blue, 
in a modification of the method according to Phillips and Hayman [24]. For evaluation we ised a microscope slide with a scale of $1 \mathrm{~mm}$ spaced lines. The assessment was carried out by the classical grid line intersected method always with four mixed samples (collected from 10 welldeveloped, typical roots of 20 plants) from each variant. For calculating the percentage colonisation the equation we used was $(\% \mathrm{C}): \% \mathrm{C}=100 \Sigma(+) / \Sigma(+)+\Sigma(-)$ according to McGonigle et al. [25].

The nitrates content of leek white shafts washed in deionised water were determined with an ion-selective electrode (ISE, Monokrystaly Turnov.cz). The electrical potential in the leachate of the vegetable tissue was measured (using an ISE), which was compared with a reference mercury sulfate electrode.

To determine zinc, lead, copper, and cadmium, 20 plants per treatment were washed in deionised water, and the uniform white shafts were the material for analysis. The method used was flow-through stripping chronopotentiometry (EcaFlow, ISTRAN, SK) after mineralisation of the sample with nitric acid.

\section{Weather Condition Measurements}

During the field experiment, the weather conditions (mean monthly temperature and precipitation) and data on sunshine duration, defined as number of hours in which the solar radiation falls on a plane, were recorded by automatic sensors located near the experimental field (Fig. 1). In 2014 and 2015 mean monthly temperature (April-October) was 15.8 and $16.4^{\circ} \mathrm{C}$, respectively. In the 2014 growing period, plants experienced high precipitation, especially in August and September, accompanied by lower sunshine duration.

\section{Statistical Analyses}

Data were analysed by ANOVA. If significant differences were detected between the treatments, the averages were compared using the Scheffe test at a probability $\alpha=0.05$.

\section{Results}

Colonisation of leek plants in both years in the control variant was in the range between $9.5 \%$ (2014) and 10.7\%

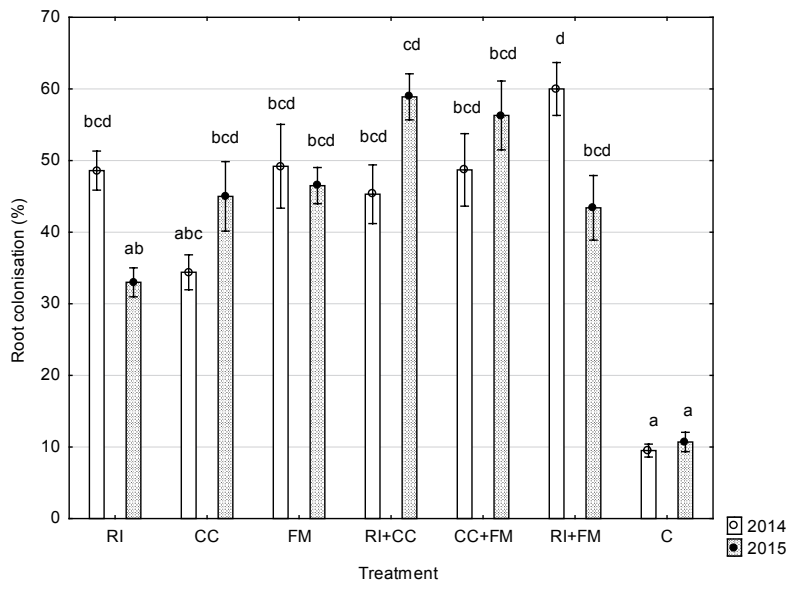

Fig. 2. Percentage of colonisation of roots by AMF by Scheffe's test $(\mathrm{P}<0.05)$.

Error bars represent SD. Abbreviations: RI - Rhizophagus intraradices, CC - Claroideoglomus claroideum, FM Funneliformis mosseae, and three mixed variants labelled $\mathrm{RI}+\mathrm{CC}, \mathrm{CC}+\mathrm{FM}$, and $\mathrm{RI}+\mathrm{FM}$.

(2015) of root length colonised with AMF. As is clear from Fig. 2, the highest level of colonisation in 2014 was shown in the variant combining $R$. intraradices and F. mosseae (RI+FM 60.0\%). The other variants showed a level of colonisation in the range $45.3 \%$ to $49.2 \%$. The lowest level of colonisation was found in the variant treated with C. claroideum (CC 34.4\%). In 2015 the rate of root colonisation was comparable with the previous year. A lower percentage of root colonisation than in 2014 was determined in the variants RI (33.0\%), FM (46.5\%), and RI+FM (43.4\%). However, the differences were not significant. The highest rate of colonisation in 2015 was determined in the variant combining $R$. intraradices and C. claroideum (RI+CC 58.9\%).

Demonstrable differences between the control variant and the variants treated with AM fungi were confirmed in the majority of cases in both experimental years. In 2014 only the difference between the control and variant $\mathrm{CC}$ (34.4\%) was not statistically confirmed. Similarly, in 2015 the difference between the control and variant RI (33.0\%) was not statistically significant.

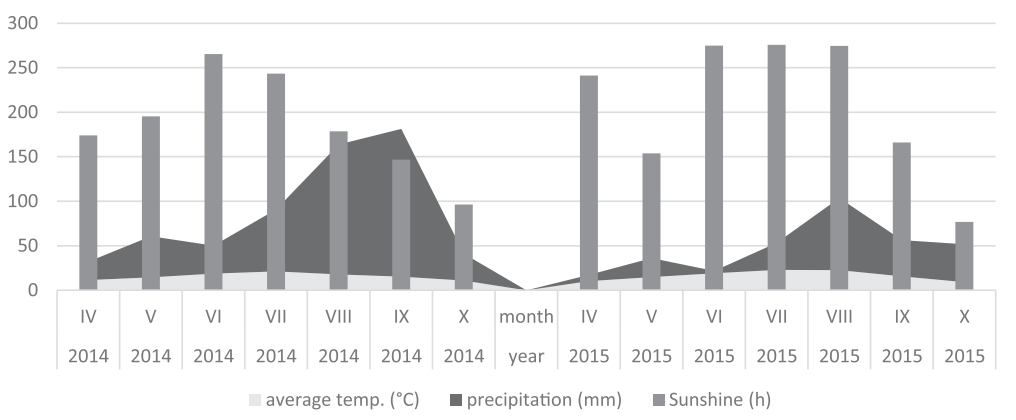

Fig. 1. Variations of temperature, precipitation, and sunshine in experimental years 2014 and 2015. 


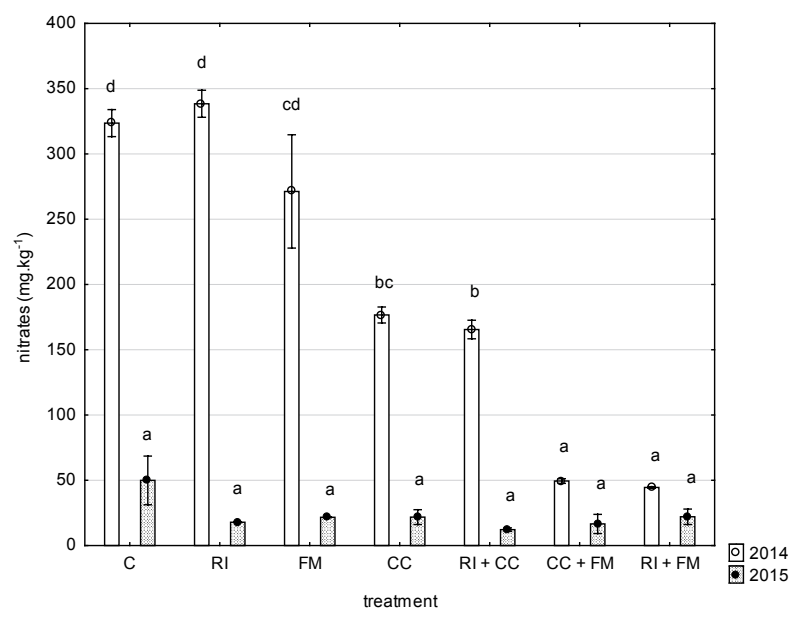

Fig. 3. Nitrates content $\left(\mathrm{mg} \cdot \mathrm{kg}^{-1} \mathrm{FW}\right)$ in leek white shaft by Scheffe's test $(\mathrm{P}<0.05)$.

Error bars represent SD. Abbreviations: RI - Rhizophagus intraradices, CC - Claroideoglomus claroideum, FM Funneliformis mosseae, and three mixed variants labelled $\mathrm{RI}+\mathrm{CC}, \mathrm{CC}+\mathrm{FM}$, and $\mathrm{RI}+\mathrm{FM}$.

In 2014 the highest content of nitrates was found in the variant treated with the fungus $R$. intraradices (RI $338.5 \mathrm{mg} \mathrm{kg}^{-1}$; Fig. 3). The second highest content was monitored in the control untreated variant (C 323.6 $\mathrm{mg} \mathrm{kg}^{-1}$ ). Between the control variant $(\mathrm{C})$ and variants $\mathrm{RI}$ and $\mathrm{FM}$ there were no significant differences, while all the other variants $(\mathrm{CC}, \mathrm{RI}+\mathrm{CC}, \mathrm{CC}+\mathrm{FM}, \mathrm{RI}+\mathrm{FM})$ have a significantly lower content of nitrates in comparison with the control. The variants treated with a combination of two AM inoculums included the lowest nitrates content, CC+FM (49.5 mg kg-1) and RI+FM (44.6 mg kg-1), both using the species $F$. mosseae in combination. In the 2014 assessment, the positive trend for combined AM fungi reducing nitrates content in plants was confirmed. In 2015 the overall nitrates content in leeks was extremely low.

In 2015 all the tested variants had a value for nitrates content under $60.0 \mathrm{mg} \cdot \mathrm{kg}^{-1}$. Despite these extremely low values, once more a positive trend for the reduction of content after inoculation with AM fungi and their combinations was found, since the untreated control variant showed the highest nitrates content in fresh leek matter (C $49.9 \mathrm{mg} \mathrm{kg}^{-1}$ ). The lowest nitrates content was determined in the variants $\mathrm{RI}+\mathrm{CC}\left(12.2 \mathrm{mg} \mathrm{kg}^{-1}\right)$ and $\mathrm{CC}+\mathrm{FM}$ (16.6 $\mathrm{mg} \mathrm{kg}^{-1}$ ), combining C. claroideum. Despite marked differences with the control variants, these differences were not confirmed by statistical analysis.

From the results of assessing the heavy metals content it can be stated that in 2014 no significant differences between the control variant and those treated with AM fungi (see Figs 4 and 5) were confirmed. The control variant (C) contained 2,611.3 $\mu \mathrm{g} \mathrm{kg}^{-1}$ zinc, $16.5 \mu \mathrm{g} \mathrm{kg}^{-1}$ lead, $8.9 \mu \mathrm{g} \mathrm{kg}^{-1}$ cadmium, and $160.7 \mu \mathrm{g} \mathrm{kg}^{-1}$ copper. The highest zinc content in 2014 was determined in the variant $\mathrm{CC}+\mathrm{FM}\left(3,017.4 \mu \mathrm{g} \mathrm{kg}^{-1}\right)$, and this variant also had the highest amount of cadmium (18.3 $\left.\mu \mathrm{g} \mathrm{kg}^{-1}\right)$. The largest amount of lead was contained in the variant RI+FM (45.1 $\left.\mu \mathrm{g} \mathrm{kg}^{-1}\right)$ and of copper was in variant CC $\left(160.9 \mu \mathrm{g} \mathrm{kg}^{1}\right)$.

In 2015, compared with 2014, an increase in the accumulation of HMs was determined. However, the only significant difference between years was marked in variant $\mathrm{RI}+\mathrm{CC}$ in case of lead content and in variant RI in case of copper content. In the control variant, $2,597.3 \mu \mathrm{g} \mathrm{kg}^{-1} \mathrm{zinc}$, $476.2 \mu \mathrm{g} \mathrm{kg}^{-1}$ copper, $57.5 \mu \mathrm{g} \mathrm{kg}^{-1}$ lead, and $17.9 \mu \mathrm{g} \mathrm{kg}^{-1}$ cadmium was determined. In the case of the evaluation of

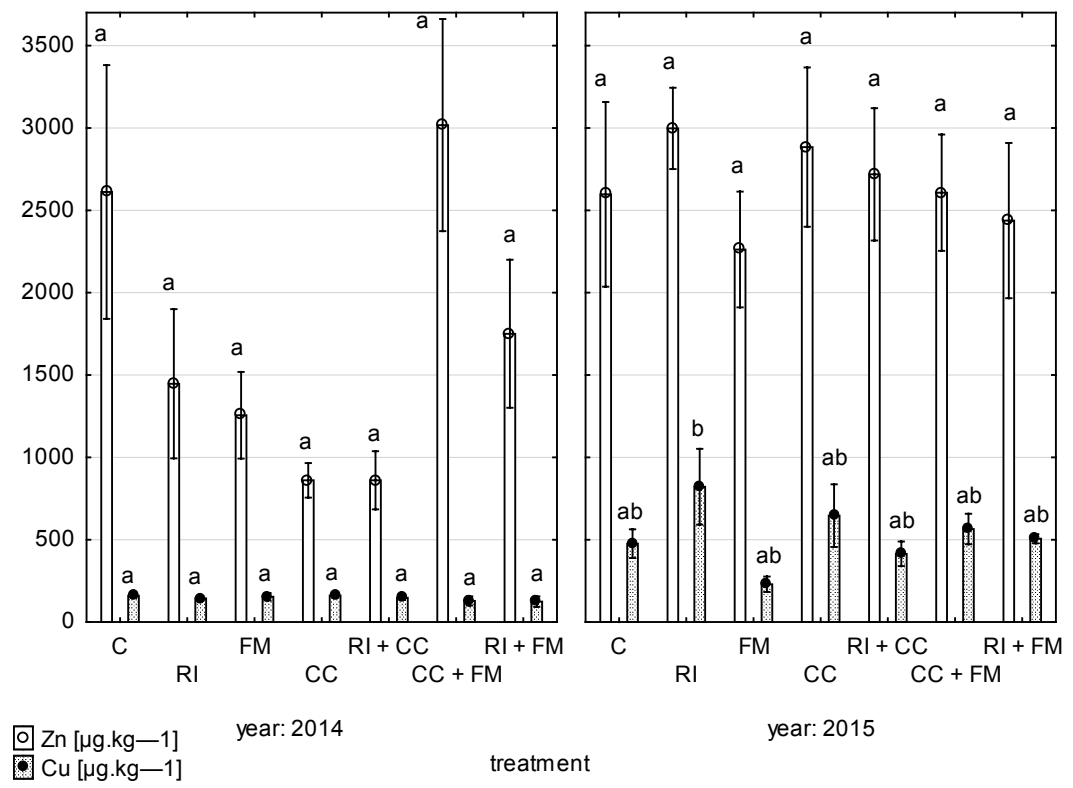

Fig. 4. $\mathrm{Zn}$ and $\mathrm{Cu}$ content $\left(\mu \mathrm{g} \cdot \mathrm{kg}^{-1} \mathrm{FW}\right)$ in leek white shaft by Scheffe's test $(\mathrm{P}<0.05)$.

Error bars represent SD. Abbreviations: RI - Rhizophagus intraradices, CC - Claroideoglomus claroideum, FM - Funneliformis mosseae, and three mixed variants labelled $\mathrm{RI}+\mathrm{CC}, \mathrm{CC}+\mathrm{FM}$, and $\mathrm{RI}+\mathrm{FM}$. 


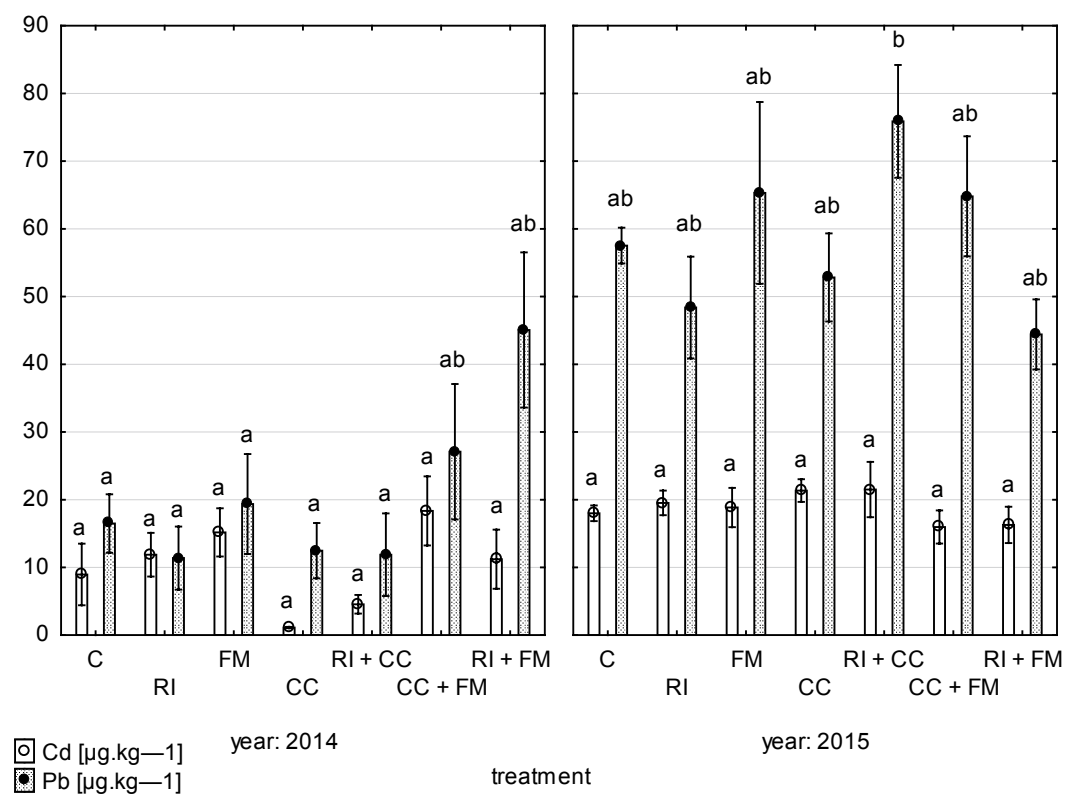

Fig. 5. Cd and $\mathrm{Pb}$ content $\left(\mu \mathrm{g} \cdot \mathrm{kg}^{-1} \mathrm{FW}\right)$ in leek white shaft by Scheffe's test $(\mathrm{P}<0.05)$.

Error bars represent SD. Abbreviations: RI - Rhizophagus intraradices, CC - Claroideoglomus claroideum, FM - Funneliformis mosseae, and three mixed variants labelled $\mathrm{RI}+\mathrm{CC}, \mathrm{CC}+\mathrm{FM}$, and $\mathrm{RI}+\mathrm{FM}$.

the zinc content the lowest amount was determined in the variant FM $\left(2,262.2 \mu \mathrm{g} \mathrm{kg}^{-1}\right)$ and the highest in the variant RI $\left(2,997.5 \mu \mathrm{g} \mathrm{kg}^{-1}\right)$. Results do not show any statistical difference between treatments in heavy metal evaluation during 2015.

From the summary of the analysis of variance (Table 1) it is obvious that the effect of production season (year) on HMs was much stronger that the effect of AMF treatment. In the case of nitrates, both the year and treatment significantly influenced the content in leek white shaft tissues.

\section{Discussion}

A number of farming practices such as the intensity of tillage, crop rotation, and overall management of horticultural produce can influence the colonisation of plant roots by arbuscular mycorrhizal fungi [26]. In many cases, increasing the yield of cultivated plants depends on naturally occurring AMF - frequently from the family Glomeraceae, which comprises seven genera (Glomus, Dominikia, Funneliformis, Kamienskia, Rhizophagus, Sclerocystis, and Septoglomus) [2628]. Plants that do not form mycorrhizal symbioses, or plants with a low colonisation potential such as pepper (Capsicum annuum L.) or lettuce (Lactuca sativa L.), can have a negative influence on the development of AM fungi in the soil [26]. It can be said that in both years of this experiment a sufficient level of colonisation was shown in all the species used. Although there was a tendency of higher colonisation potential of mixed AMF communities (RI+FM in 2014; RI+CC; CC+FM in 2015), differences were not confirmed statistically.

In many species of plants nitrogen can accumulate in the form of undesirable nitrates. Inorganic nitrogen is taken up by plants from the soil in two forms $\left(\mathrm{NO}^{3}, \mathrm{NH}^{4+}\right)$, and in the presence of AM fungi it is absorbed in the extraradical mycelia, where it is converted into the amino acid arginine and transported to the intraradical mycelia [29-30]. Significant differences were determined between individual years in nitrates content. In 2014 the results

Table 1. Summary of analysis of variance for heavy metals and nitrates in two years of leek cultivation.

\begin{tabular}{|c|c|c|c|c|c|}
\hline Source of variance & $\mathrm{Zn}$ & $\mathrm{Cd}$ & $\mathrm{Pb}$ & $\mathrm{Cu}$ & Nitrates \\
\hline AMF treatment & NS & NS & NS & NS & $* * *$ \\
\hline Year & $* *$ & $* * *$ & $* * *$ & $* * *$ & $* * *$ \\
\hline AMF treatment $\times$ year & NS & NS & $*$ & NS & $* * *$ \\
\hline
\end{tabular}

Differences in heavy metals and nitrates depending on treatment and year by Scheffe test; non-significant (NS) or significant at $P \leq 0.05(*), 0.01\left(^{* *}\right)$, or $0.001(* *)$, respectively 
of nutritional tests confirmed the working hypothesis (a reduction in the nitrates content in inoculated plants), with the exception of the variant $R$. intraradices (RI $338.5 \mathrm{mg}$ $\mathrm{kg}^{-1}$ ), which had the highest content of undesirable nitrates. The second highest nitrates content was determined in the control variant (C $323.6 \mathrm{mg} \mathrm{kg}^{-1}$ ), where a higher concentration was anticipated. The 2014 evaluation of the nitrates content confirmed the positive trend toward reducing nitrates in plants with the use of AM fungi. In the variants treated with a combination of two AM fungi, the nitrates content in the plant fell significantly, $\mathrm{RI}+\mathrm{CC}$ (165.5 mg kg-1), CC+FM (49.5 mg kg-1), and RI+FM (44.5 mg kg-1). In 2015 all the tested variants had values under $60.0 \mathrm{mg} \mathrm{kg}^{-1}$. The marked reduction in nitrates in this year compared to 2014 may be due to higher enzymatic activity leading to a reduction in nitrates. The enzymes nitrate reductase and nitrite reductase are primarily influenced by light (nitrates accumulate when there is insufficient light), but also heat [31-32]. Therefore, it is possible that due to the greater number of warm days and days with higher solar activity and lower precipitation in 2015 (Fig. 1), the content of nitrates in the tissue was reduced. Even despite these extremely low values, a renewed positive trend with the inoculation of AM fungi and their combinations was recorded. The control showed the highest content of nitrates $\left(\mathrm{C} 49.9 \mathrm{mg} \mathrm{kg}^{-1}\right)$. The lowest nitrates content was determined in the variants $\mathrm{RI}+\mathrm{CC}$ (12.2 $\left.\mathrm{mg} \mathrm{kg}^{-1}\right), \mathrm{CC}+\mathrm{FM}$ (16.6 $\left.\mathrm{mg} \mathrm{kg}^{-1}\right)$, RI (17.9 $\mathrm{mg} \mathrm{kg}^{-}$ $\left.{ }^{1}\right)$, and $\mathrm{CC}\left(21.8 \mathrm{mg} \mathrm{kg}^{-1}\right)$. Although the positive effect of selected AM fungi on the nitrates content has been shown, it is necessary to keep in mind the importance of the factor of climatic conditions, which in 2015 had a significant effect on nitrates content (Table 1).

Increased zinc content in leeks is mentioned by Sorensen et al. [12] when observing the influences in soil with freely occurring AMF. Similar results were obtained in an experiment with pepper plants (Capsicum annuиm L.). An increase in zinc and phosphorus content took place even when cultivating peppers on soil that was poor in these elements. Treatment with AM fungi showed the highest increase in zinc content in the variant treated with the Iranian species of $C$. etunicatum (S2C1M3). Diaz et al. [33] showed that heavy metal uptake by AMF plants increased with low heavy metal concentrations, but decreased under high heavy metal concentrations. The protective behaviour of AMF under toxic heavy metal concentrations was attributed to possible binding of the metals in the extraradical hyphae or to the limiting of their translocation to shoots [34]. The uptake/binding phenomena has also been observed in two recent studies on Solanum nigrum [35] and grafted tomato [36]. Our experimental field was characterised by HM content reported for uncontaminated soils [23]. Such conditions can initiate a mechanism of HMs unbinding from soil sorption complex by AMF, accumulation, and translocation into plant tissues. However, the presence of the uptake/binding phenomena described by other authors could not be confirmed in this experiment. In both years, no significant differences between the untreated control variant and the variants treated with the mycorrhizal fungi were confirmed in plants. The differences in HMs only manifested between the years (Table 1). The greater sunlight and higher temperatures in 2015 had a clear effect on HM content, which in this warm year reached higher levels than in 2014, regardless of the presence of AM inoculant.

From these results, it is possible once more to state the significance of the factor of climatic conditions on the accumulation of heavy metals, which can override the effect of mycorrhizal inoculation on the parameters assessed. Commission Regulation (EC) No. 1881/2006 set maximum levels for $\mathrm{Cd}$ and $\mathrm{Pb}$ contaminants in vegetables: for $\mathrm{Cd}\left(0.05-0.10 \mathrm{mg} \mathrm{kg}^{-1} \mathrm{FW}\right)$ and $\mathrm{Pb}$ (0.1-0.3 $\left.\mathrm{mg} \mathrm{kg}^{-1} \mathrm{FW}\right)$. In light of the European law, the levels of $\mathrm{Cd}$ and $\mathrm{Pb}$ in leeks treated with $\mathrm{AMF}$ is in line with limits. $\mathrm{Cu}$ and $\mathrm{Zn}$ should be considered both heavy metals and nutrients, according to their physiological roles and contents in plants. The EU has not established maximum levels for these micro elements in food. According to Kabata-Pendias [23], the most recent reference for food composition in the United States gives the following range for $\mathrm{Cu}$ values in vegetables of 0.1-3.2 $\mathrm{mg} \mathrm{kg}^{-1} \mathrm{FW}$, and $0.7-8.0 \mathrm{mg} \mathrm{kg}^{-1} \mathrm{FW}$ for $\mathrm{Zn}$. Concentrations of $\mathrm{Zn}$ and $\mathrm{Cu}$ in leeks was within the cited range. This points to the high degree of bio-availability of these metals in leeks.

\section{Conclusions}

Many authors have described the positive influence of AM inoculation on the content of substances in various vegetables. In this experiment a sufficient level of inoculation was achieved in the leek roots. Although a tendency toward a reduction in nitrates content was apparent, the positive effect of selected AM fungi on nitrates content was statistically proven only in one season (2014). The effects of climatic conditions in 2015 had a more significant effect on nitrate content in comparison with the inoculant used. From the evaluation of the heavy metals content a certain influence by AM inoculant can be recorded. The course of the weather evidently had an effect on the zinc, lead, copper, and cadmium contents, where in the warmer year 2015 higher content figures were recorded than in 2014, regardless of the presence of $\mathrm{AM}$ inoculants. In light of food safety, $\mathrm{Cd}$ and $\mathrm{Pb}$ contents in leek white shaft were below maximum levels for these contaminants effective in EU.

\section{Acknowledgements}

This work was supported by grant TA02020544 of the Technology Agency of the Czech Republic. 


\section{References}

1. SMITH S.E., READ D.J. Mycorrhizal symbiosis. Academic Press, New York, USA, 2008.

2. REINHARDT D. Programming good relations - development of the arbuscular mycorrhizal symbiosis. Curr. Opin. Plant Biol., 10 (1), 98, 2007.

3. KOIDE R.T., MOSSE B.A history of research on arbuscular mycorrhiza. Mycorrhiza, 14 (3), 145, 2004.

4. SMITH J.E. Mycorrhizal Symbiosis. Soil Sci. Soc. Am. J. 73 (2), 694, 2009.

5. WILLIS A., RODRIGUES B.F., HARRIS P.J.C. The ecology of arbuscular mycorrhizal fungi. Crit. Rev. Plant Sci. 32 (1), 1, 2013.

6. SMITH S. Arbuscular Mycorrhizas: Physiology and Function. Soil Biol. Biochem. 33 (11), 1575, 2001.

7. ANTUNES P.M., SCHNEIDER K., HILLIS D., KLIRONOMOS J.N. Can the arbuscular mycorrhizal fungus Glomus intraradices actively mobilize P from rock phosphates? Pedobiologia 51 (4), 281, 2007.

8. BAUM C., EL-TOHAMY W., GRUDA N. Increasing the productivity and product quality of vegetable crops using arbuscular mycorrhizal fungi: A review. Sci. Hort. 187, 131, 2015.

9. HART M., EHRET D.L., KRUMBEIN A., LEUNG C., MURCH S., TURI C., FRANKEN P. Inoculation with arbuscular mycorrhizal fungi improves the nutritional value of tomatoes. Mycorrhiza, 25, 359, 2015.

10. ELBON A., WHALEN J.K. Phosphorus supply to vegetable crops from arbuscular mycorrhizal fungi: a review. Biol. Agric. Hortic. 31 (2), 73, 2015.

11. BASLAM M., GARMENDIA I., GOICOECHEA N. The arbuscular mycorrhizal symbiosis can overcome reductions in yield and nutritional quality in greenhouse-lettuces cultivated at inappropriate growing seasons. Sci. Hort. 164, 145, 2013.

12. SORENSEN J.N., LARSEN J., JAKOBSEN I. Mycorrhiza formation and nutrient concentration in leeks (Allium porrum) in relation to previous crop and cover crop management on high P soils. Plant Soil 273 (1-2), 101, 2005.

13. CHEN X., TANG J., ZHI G., HU S. Arbuscular mycorrhizal colonization and phosphorus acquisition of plants: Effects of coexisting plant species. Appl. Soil Ecol. 28 (3), $259,2005$.

14. ÇEKIÇ F.Ö., ÜNYAYAR S., ORTAŞ İ. Effects of arbuscular mycorrhizal inoculation on biochemical parameters in Capsicum annuum grown under long term salt stress. Turk. J. Bot. 36 (1), 63, 2012.

15. BONAE., CANTAMESSAS.,MASSAN., MANASSEROP., MARSANO F., COPETTA A., LINGUA G., D'AGOSTINO G., GAMALERO E., BERTA G. Arbuscular mycorrhizal fungi and plant growth-promoting pseudomonads improve yield, quality and nutritional value of tomato: a field study. Mycorrhiza 27, 1, 2017.

16. ABDEL LATEF A.A.H., CHAOXING H. Effect of arbuscular mycorrhizal fungi on growth, mineral nutrition, antioxidant enzymes activity and fruit yield of tomato grown under salinity stress. Sci. Hort. 127 (3), 228, 2011.

17. GIOVANNETTI M., AVIO L., BARALE R., CECCARELLI N., CRISTOFANI R., IEZZI A., MIGNOLLI F., PICCIARELLI P., PINTO B., REALI D., SBRANA C., SCARPATO R. Nutraceutical value and safety of tomato fruits produced by mycorrhizal plants. Br. J. Nutr. 107 (2), 242, 2012.
18. ORDOOKHANI K., KHAVAZI K., MOEZZI A., REJALI F. Influence of PGPR and AMF on antioxidant activity, lycopene and potassium contents in tomato. Afr. J. Agric. Res. 5 (10), 1108, 2010.

19. PERNER H., ROHN S., DRIEMEL G., BATT N., SCHWARZ D., KROH L.W., GEORGE E. Effect of nitrogen species supply and mycorrhizal colonization on organosulfur and phenolic compounds in onions. J. Agric. Food Chem. 56 (10), 3538, 2008.

20. MALIK N.S.A., NUÑEZ A., MCKEEVER L.C., KUNTA M., DOUDS D., NEEDLEMAN D.S. Mycorrhizal fungi collected from the rhizospheres around different olive cultivars vary in their ability to improve growth and polyphenol levels in leeks. J. Agric. Sci. 8 (8), 32, 2016.

21. PAUN A., NEAGOE A., PAUN M., BACIU I., IORDACHE V. Heavy metal-induced differential responses to oxidative stress and protection by mycorrhization in sunflowers grown in lab and field scales. Pol. J. Environ. Stud. 24 (3), 1235, 2015.

22. SYMBIOM.CZ. Symbiom - Dávkování přípravků. Retrieved November 21, 2015, from http://www.symbiom. cz/davkovani (2015).

23. KABATA-PENDIAS A. Trace Elements in Soils and Plants. CRC Press, US, 2010.

24. PHILLIPS J.M., HAYMAN D.S. Improved procedures for clearing roots and staining parasitic and vesicular-arbuscular mycorrhizal fungi for rapid assessment of infection. Trans. Brit. Mycol. Soc. 55 (1), 158, 1970.

25. MCGONIGLE T., MILLER M., EVANS D.G., FAIRCHILD G.L., SWAN J.A. A new method which gives an objective measure of colonization of roots by vesicular-arbuscular mycorrhizal fungi. New Phytol. 115, 495, 1990.

26. ROUPHAEL Y., FRANKEN P., SCHNEIDER C., SCHWARZ D., GIOVANNETTI M., AGNOLUCCI M., COLLA G. Arbuscular mycorrhizal fungi act as biostimulants in horticultural crops. Sci. Hort. 196, 91, 2015.

27. REDECKER D., SCHÜSSLER A., STOCKINGER H., STÜRMER S.L., MORTON J.B., WALKER C. An evidence-based consensus for the classification of arbuscular mycorrhizal fungi (Glomeromycota). Mycorrhiza 23 (7), 515, 2013.

28. OEHL F., DA SILVA G.A., GOTO B.T., SIEVERDING E. Glomeromycota: three new genera and glomoid species reorganized. Mycotaxon 116 (1), 75, 2011.

29. TIAN C., KASIBORSKI B., KOUL R., LAMMERS P.J., BÜCKING H., SHACHAR-HILL Y. Regulation of the nitrogen transfer pathway in the arbuscular mycorrhizal symbiosis: gene characterization and the coordination of expression with nitrogen flux. Plant Physiol 153 (3), 1175, 2010.

30. BEHIE S.W., BIDOCHKA M.J. Nutrient transfer in plant-fungal symbioses. Trends Plant Sci. 19 (11), 734, 2014.

31. RIOS J.J., BLASCO B., ROSALES M.A., SANCHEZRODRIGUEZ E., LEYVA R., CERVILLA L.M., RUIZ J.M. Response of nitrogen metabolism in lettuce plants subjected to different doses and forms of selenium. J. Sci. Food Agric. 90 (11), 1914, 2010.

32. SANMARTÍN C., GARMENDIA I., ROMANO B., DÍAZ M., PALOP J.A., GOICOECHEA N. Mycorrhizal inoculation affected growth, mineral composition, proteins and sugars in lettuces biofortified with organic or inorganic selenocompounds. Sci. Hort. 180, 40, 2014.

33. DIAZ G., AZCÓN-AGUILAR C., HONRUBIA M. Influence of arbuscular mycorrhizae on heavy metal ( $\mathrm{Zn}$ and 
$\mathrm{Pb})$ uptake and growth of Lygeum spartum and Anthyllis cytisoides. Plant Soil 180 (2), 241, 1996.

34. MOZAFAR A., RUH R., KLINGEL P., GAMPER H., EGLI S., FROSSARD E. Effect of heavy metal contaminated shooting range soils on mycorrhizal colonization of roots and metal uptake by leek. Environ. Monit. Assess. 79 (2), 177, 2002.

35. LIU H., YUAN M., TAN S., YANG X., LAN Z., JIANG Q., JING Y. Enhancement of arbuscular mycorrhizal fungus
(Glomus versiforme) on the growth and $\mathrm{Cd}$ uptake by $\mathrm{Cd}-$ hyperaccumulator Solanum nigrum. Appl. Soil Ecol. 89 (89), 44, 2015.

36. KUMAR P., LUCINI L., ROUPHAEL Y., CARDARELLI M., KALUNKE R.M., COLLA G. Insight into the role of grafting and arbuscular mycorrhiza on cadmium stress tolerance in tomato. Front. Plant Sci. 6, 477, 2015. 